\title{
A Compari`Tive Study between Vecuronium and Rocuronium for Intubating Condition and Hemodynamic Changes
}

\author{
${ }^{1}$ M. Somani, ${ }^{2}$ P. Sharma, ${ }^{3}$ S. Sachdev, ${ }^{4}$ V. Mathur, ${ }^{5}$ S. Chaturvedi \\ 1,2,3,4,5 Department of Anaesthesia and Critical Care, Mahatma Gandhi Medical college, Jaipur
}

\begin{abstract}
Background: Neuromuscular blockers (NMB) are very important for generalanesthesia, Rocuronium and Vecuronium are used as non-depolarizing muscle relaxants. In a randomized study we had compared both drugs as regard theonset of action, intubating condition and hemodynamic changes.

Method:-Sixty patients ( 20 to 60 year), scheduled to undergo elective general surgery, were included in thisrandomized, double-blind controlledstudy.After induction of anaesthesia, patientswere divided randomly into two groups according to the muscle relaxant used. Group I received Inj. rocuronium while GroupII received Inj.vecuronium.Haemodynamic parameters comprising of heart rate, mean arterial pressure were measuredpreoperatively, pre induction, post induction, post relaxant, post intubation $(1 \mathrm{~min})$ and after 3 , 5,7,10,15 and 30 min after intubation.

Results:-Rocuronium has maintained excellent cardiovascular stability for the dose used in present study. There was an increase inheart rate following rocuronium administration but the average maximum increase of 5 beats/min was clinically insignificant.Rocuronium is 3-6 times less potent than vecuronium as a neuromuscular blocker but is slightly more potent in blocking theresponses to either vagal or preganglionic sympathetic stimulation.
\end{abstract}

Keywords: Intubating conditions, Vecuronium, Rocuronium, Hemodynamic changes

\section{Introduction}

Rapid and safe endotracheal intubation is of paramount importance in the practice of general anaesthesia. Role of muscle relaxation is used to serve two prime purposes ${ }^{1}$, to facilitate endotracheal intubation and the other, to provide surgical relaxation ${ }^{2}$.The ease in performing endotracheal intubation, depends upon degree of muscle relaxation, depth of anaesthesia and skill of anaesthesiologist ${ }^{1}$.The onset time, duration of a muscle relaxation and type of surgery are critical factors in choosing the appropriate muscle relaxant to achieve rapid successful tracheal intubation ${ }^{3}$. Dale discovered the role of acetylcholine in neuromuscular transmission and gave new insights in the Structure Activity Relationship of muscle relaxants and the basic differentiation of two classes of muscle relaxants-the depolarizers (succinylcholine 1950) and non depolarizers(tubocurarine1942).Succinylcholine reliably produces muscle relaxation within 60 seconds of its administration. The introduction of rocuronium bromide, ORG-9426, a non depolarizing agent with a quick onset and intermediate duration of action, has one sixth of potency of vecuronium and is extremely cardiostable and has a rapid onset of action, which would render it the muscle relaxant of choice for facilitation of both routine and crash intubation. Rocuronium has the onset time comparable to succinylcholine. The present study was undertaken to compare the haemodynamic effects and intubating conditions using vecuronium versus rocuronium in patients undergoing general surgical procedures.

\section{Method}

Sixty patients (ASA Grade I or II) between ages of 20 and 60 year, scheduled to undergo elective general surgery, were included in thisrandomized, double-blind controlled study after obtaining their written informed consent and approval from the Hospital Ethical Committee in Mahatma Gandhi Medical College, Jaipur during 2011- 2013. Patients with a left ventricular ejection fraction of less than 50\% or suffering from valvular heart disease or hepatic, renal or neurological disorders or using drugs that might affect neuromuscular transmission were excluded from the study. All patients were in sinus rhythm on arrival in the operating room. Monitoring of heart rate and rhythm with five lead ECG monitor was commenced on arrival in the operating room. Peripheral venous cannulation was done for l.V. fluid and drug infusion. The small silver electrodes of the peripheral nerve stimulator were placed so as to stimulate the ulnar nerve and to monitor effect of neuromuscular blocking agents.

The parameters observed during the study were heart rate, electrocardiograph (ECG), oxygen saturation $(\mathrm{SpO} 2)$ and end tidal carbon dioxide $(\mathrm{EtCO})$. Baseline recordings of heart rate and mean systemic arterial pressure (MAP), were measured.

After preoxygenation for three minutes anaesthesia was induced with inj. Glycopyrrolate $(0.01 \mathrm{mg} / \mathrm{kg})$ i.v., inj. Butorphanol $(0.02 \mathrm{mg} / \mathrm{kg})$, inj. Midazolam $(0.02 \mathrm{mg} / \mathrm{kg})$ i.v. followed by $2.5 \%$ thiopentone sodium (3-4 
$\mathrm{mg} / \mathrm{kg}$ ) i.v. slowly and loss of eyelash reflex were considered as endpoint of induction. Patients were randomly allocated to receive inj. Vecuronium $0.1 \mathrm{mg} / \mathrm{kg}$ (group I:n=30) or inj. Rocuronium $0.6 \mathrm{mg} / \mathrm{kg}$ (group II: $\mathrm{n}=30$ ) intravenously. The onset time of the muscle relaxant was determined by measuring the time from injection of relaxant to $100 \%$ depression of the first response i.e. T1. The supramaximal stimulus of duration $0.2 \mathrm{~ms}$ and frequency $2 \mathrm{~Hz}$ was delivered in a train-of-four (TOF) sequence at $12 \mathrm{~s}$ intervals to the ulnar nerve at the wrist via surface electrodes and the evoked responses of the adductor pollicis muscle was transduced and recorded using TOF Guard monitor.

Endotracheal intubation was carried out once maximum block achieved ( $\mathrm{T} 1$ response is ablated) and mechanical intermittent positive pressure ventilation instituted with $100 \% \mathrm{O} 2$. The end-tidal carbon dioxide was maintained in between 28 and $32 \mathrm{~mm}$ of $\mathrm{Hg}$.

\section{Intense blockade-no response to TOF}

Moderate or surgical blockade-response present to TOF

\begin{tabular}{|l|l|}
\hline Number & Degree of blockade \\
\hline 1 & 90 \\
\hline 2 & 85 \\
\hline 4 & 80 \\
\hline & 75 \\
\hline
\end{tabular}

Table: Scoring of intubating conditions

\begin{tabular}{|l|l|l|l|}
\hline Score & Jaw relaxation & $\begin{array}{l}\text { Vocal } \\
\text { cords }\end{array}$ & $\begin{array}{l}\text { Response to intubation } \\
\text { (laryngoscopy) }\end{array}$ \\
\hline 0 & Poor (impossible) & Closed & severe coughing or bucking \\
\hline 1 & Minimal (difficult) & Closing & Mild coughing \\
\hline 2 & Moderate (fair) & Moving & Slight diaphragmatic movement \\
\hline 3 & Good (easy) & Open & No diaphragmatic movement \\
\hline
\end{tabular}

Total score of $8-9=$ excellent; $6-7=$ good; $3-5=$ fair; $0-2=$ poor.

All the haemodynamic measurements were repeated at 2 min interval upto $10 \min (1,3,5,7$, and 10) than after 15 and $30 \mathrm{~min}$. after the injection of relaxants. All patients weregiven about $5 \mathrm{ml} / \mathrm{kg} / \mathrm{hr}$ of lactated ringer's solution during the study period. The surgical stimulation was included during the study period.

Statistical analysis of the results for each variable within each group was carried out by repeated measures analysis of variance (ANOVA \& unpaired $t$ test). Comparisons for each variable between the two groups were made using one-way analysis of variance and unpaired t-tests. $\mathrm{P}<0.05$ was considered to be significant.

With nerve stimulator the parameters measured was:

Onset time - Time required from injection of neuromuscular relaxant to $100 \%$ depression of the first response (T1) [maximum block]. The study was terminated at this stage and anaesthesia and relaxation was maintained asappropriateforsurgery.

The two groups are comparable with respect to average age, height and weight \& sex. Average values of haemodynamic variables before and after relaxant administration and changes in heart rate, mean arterial pressure were shown .There were no significant changes in heart rate and MAP in patients who received rocuronium.

Mean \pm SD of age, weight and height of the two groups using ANOVA

\begin{tabular}{|l|c|c|c|}
\hline \multicolumn{1}{|c|}{ Group } & Age & Weight & Height \\
\hline Vecuronium & $34.43 \pm 10.41$ & $66.2 \pm 10.8$ & $162.43 \pm 8.65$ \\
\hline Rocuronium & $39.97 \pm 11.37$ & $66.0 \pm 11.16$ & $163.83 \pm 8.33$ \\
\hline ANOVA F-value & 3.87 & 0 & 0.4 \\
\hline P & 0.054 (N.S) & 0.944 (N.S) & 0.526 (N.S) \\
\hline
\end{tabular}

The above table shows that both the groups were statistically comparable in regards to age, weight and height.

$\mathrm{P}$ value $>0.05-$ Not significant (N.S.)

$P$ value $<0.05-$ Significant (Sig.)

$\mathrm{P}$ value $<0.001-$ Highly significant (H.S.) 
Sex distribution in the two groups

\begin{tabular}{|l|l|l|}
\hline Group & Male & Female \\
\hline Vecuronium & 9 & 21 \\
\hline Rocuronium & 11 & 19 \\
\hline
\end{tabular}

Mean \pm SD of the time of onset of the two groups using ANOVA

\begin{tabular}{|l|l|}
\hline Group & Time of onset \\
\hline Rocuronium & $150.7 \pm 11.82$ \\
\hline Vecuronium & $99.97 \pm 10.88$ \\
\hline ANOVA F- value & 299.15 \\
\hline P & 0.000 (H.S.) \\
\hline
\end{tabular}

Above table shows the comparison of the time of onset between vecuronium and rocuronium which is highly significant statistically.

$P$ value $>0.05-$ Not significant (N.S.)

$P$ value $<0.05-$ Significant (Sig.)

$P$ value $<0.001-$ Highly significant (H.S.)

\begin{tabular}{|l|l|}
\hline $\begin{array}{l}\text { Mean } \pm \text { SD of the intubation score of the } \\
\text { two groups using ANOVA Group }\end{array}$ & Intubation score \\
\hline Vecuronium & $8.87 \pm 0.35$ \\
\hline Rocuronium & $8.93 \pm 0.25$ \\
\hline ANOVA F-value & 0.58 \\
\hline P & 0.448 (N.S.) \\
\hline
\end{tabular}

Above table shows the comparison of the intubating conditions between vecuronium and rocuronium which is not significant statistically.

$P$ value $>0.05-$ Not significant (N.S.)

$P$ value $<0.05-$ Significant (Sig.)

$\mathrm{P}$ value $<0.001-$ Highly significant (H.S.)

Mean \pm SD of heart rate of the two groups at various intervals using ANOVA

\begin{tabular}{|c|c|c|c|c|c|c|c|c|c|}
\hline Group & $\begin{array}{l}\text { Pre } \\
\text { operative }\end{array}$ & $\begin{array}{l}\text { After } \\
\text { induction }\end{array}$ & \begin{tabular}{|l|} 
After \\
intubation \\
min
\end{tabular} & $3 \mathrm{~min}$ & $5 \mathrm{~min}$ & $7 \mathrm{~min}$ & $10 \mathrm{~min}$ & $15 \mathrm{~min}$ & $30 \mathrm{~min}$ \\
\hline Vecuronium & \begin{tabular}{|l|}
$84.23 \pm$ \\
13.34 \\
\end{tabular} & $\begin{array}{l}83.4 \pm \\
16.41\end{array}$ & \begin{tabular}{|l|}
$90.87 \pm$ \\
15.8 \\
\end{tabular} & $\begin{array}{l}88.33 \pm \\
14.53\end{array}$ & $\begin{array}{l}85.83 \pm \\
15.11\end{array}$ & $\begin{array}{l}83.8 \pm \\
15.77\end{array}$ & $\begin{array}{l}80.43 \pm \\
14.28 \\
\end{array}$ & \begin{tabular}{|l|}
$77.83 \pm$ \\
13.92 \\
\end{tabular} & \begin{tabular}{|l|}
$76.6 \pm$ \\
12.84 \\
\end{tabular} \\
\hline Rocuronium & \begin{tabular}{|l|}
$83.83 \pm$ \\
16.14 \\
\end{tabular} & \begin{tabular}{|l|}
$85.33 \pm$ \\
16.67 \\
\end{tabular} & $\begin{array}{l}91 \pm \\
14.54 \\
\end{array}$ & $\begin{array}{l}89.8 \pm 1 \\
4.81 \\
\end{array}$ & $\begin{array}{l}88.6 \pm \\
16.23 \\
\end{array}$ & $\begin{array}{l}85.93 \pm \\
16.82 \\
\end{array}$ & \begin{tabular}{|l|}
$83.73 \pm$ \\
16.46 \\
\end{tabular} & \begin{tabular}{|l|}
$83.53 \pm$ \\
15.04 \\
\end{tabular} & \begin{tabular}{|l|}
$83.67 \pm$ \\
14.17 \\
\end{tabular} \\
\hline $\begin{array}{l}\text { ANOVA F- } \\
\text { value }\end{array}$ & 0.01 & 0.2 & 0 & 0.15 & 0.47 & 0.26 & 0.69 & 2.32 & 4.1 \\
\hline $\mathrm{P}$ & $\begin{array}{l}0.917 \\
\text { (N.S.) }\end{array}$ & $\begin{array}{l}0.653 \\
(\mathrm{~N} . S .)\end{array}$ & $\begin{array}{l}0.974 \\
\text { (N.S.) }\end{array}$ & $\begin{array}{l}0.699 \\
\text { (N.S.) }\end{array}$ & $\begin{array}{l}0.497 \\
(\mathrm{~N} . \mathrm{S} .)\end{array}$ & $\begin{array}{l}0.615 \\
\text { (N.S.) }\end{array}$ & $\begin{array}{l}0.41 \\
(\mathrm{~N} . \mathrm{S} .)\end{array}$ & $\begin{array}{l}0.133 \\
(\mathrm{~N} . \mathrm{S} .)\end{array}$ & $\begin{array}{l}0.047 \\
\text { (Sig.) }\end{array}$ \\
\hline
\end{tabular}

Above table shows that there significant fall in the heart rate is seen at $30 \mathrm{~min}$. after intubation in the group receiving vecuronium as compared with the group receiving rocuronium.

$P$ value $>0.05-$ Not significant (N.S.)

$P$ value $<0.05-$ Significant (Sig.)

$P$ value $<0.001-$ Highly significant (H.S.)at various time intervals. 


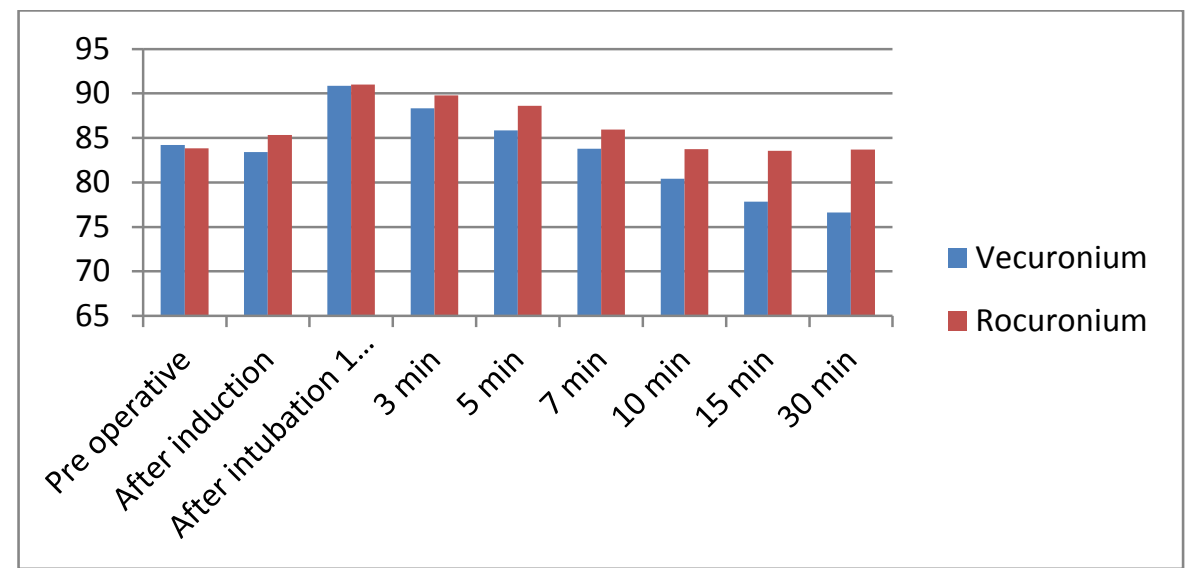

Mean \pm SD of mean arterial pressure of the two groups at various intervals using ANOVA

\begin{tabular}{|c|c|c|c|c|c|c|c|c|c|}
\hline Group & $\begin{array}{l}\text { Pre } \\
\text { operative }\end{array}$ & \begin{tabular}{|l} 
After \\
induction
\end{tabular} & \begin{tabular}{|l|}
$\begin{array}{l}\text { After } \\
\text { intubation } \\
\text { min }\end{array}$ \\
\end{tabular} & 3 min & 5 min & $7 \mathrm{~min}$ & 10 min & $15 \mathrm{~min}$ & $30 \mathrm{~min}$ \\
\hline $\begin{array}{l}\text { Vecuroniu } \\
\mathrm{m}\end{array}$ & $\begin{array}{l}93.4 \pm \\
10.19\end{array}$ & $\begin{array}{l}89.3 \pm \\
12.58\end{array}$ & $\begin{array}{l}94.13 \pm \\
13.15\end{array}$ & $\begin{array}{l}90.73 \pm \\
11.91\end{array}$ & $\begin{array}{l}89.03 \pm \\
10.5\end{array}$ & $\begin{array}{l}90.8 \pm \\
9.22\end{array}$ & $\begin{array}{l}92.83 \pm \\
9.74\end{array}$ & $\begin{array}{l}94.06 \pm \\
12.64\end{array}$ & $\begin{array}{l}95.43 \pm \\
11.98\end{array}$ \\
\hline $\begin{array}{l}\text { Rocuroniu } \\
\mathrm{m}\end{array}$ & $\begin{array}{l}94.2 \pm \\
10.44\end{array}$ & $\begin{array}{l}91.23 \pm \\
9.86 \\
\end{array}$ & $\begin{array}{l}96.1 \pm \\
12.97 \\
\end{array}$ & $\begin{array}{l}92.73 \pm \\
9.22\end{array}$ & $\begin{array}{l}92.5 \pm \\
9.6\end{array}$ & $\begin{array}{l}92.27 \pm \\
9.8\end{array}$ & $\begin{array}{l}92.43 \pm \\
9.85 \\
\end{array}$ & $\begin{array}{l}92.33 \pm \\
7.89 \\
\end{array}$ & $\begin{array}{l}92.27 \pm \\
9.21\end{array}$ \\
\hline $\begin{array}{l}\text { ANOVA } \\
\text { F-value }\end{array}$ & 0.09 & 0.661 & 0.34 & 0.53 & 1.78 & 0.36 & 0.03 & 0.4 & 1.31 \\
\hline $\mathrm{P}$ & \begin{tabular}{|l|}
0.765 \\
(N.S.)
\end{tabular} & \begin{tabular}{|l|}
0.511 \\
(N.S.)
\end{tabular} & \begin{tabular}{|l|}
0.561 \\
(N.S.)
\end{tabular} & $\begin{array}{l}0.47 \\
\text { (N.S.) }\end{array}$ & \begin{tabular}{|l|}
0.187 \\
(N.S.) \\
\end{tabular} & \begin{tabular}{|l|}
0.552 \\
(N.S.)
\end{tabular} & $\begin{array}{l}0.875 \\
\text { (N.S.) }\end{array}$ & $\begin{array}{l}0.527 \\
\text { (N.S.) }\end{array}$ & $\begin{array}{l}0.257 \\
\text { (N.S.) }\end{array}$ \\
\hline
\end{tabular}

Above table shows that there no significant changes are seen in the mean arterial pressure between the two groups at various time intervals.

$P$ value $>0.05-$ Not significant (N.S.)

$P$ value $<0.05-$ Significant (Sig.)

$P$ value $<0.001-$ Highly significant (H.S.)

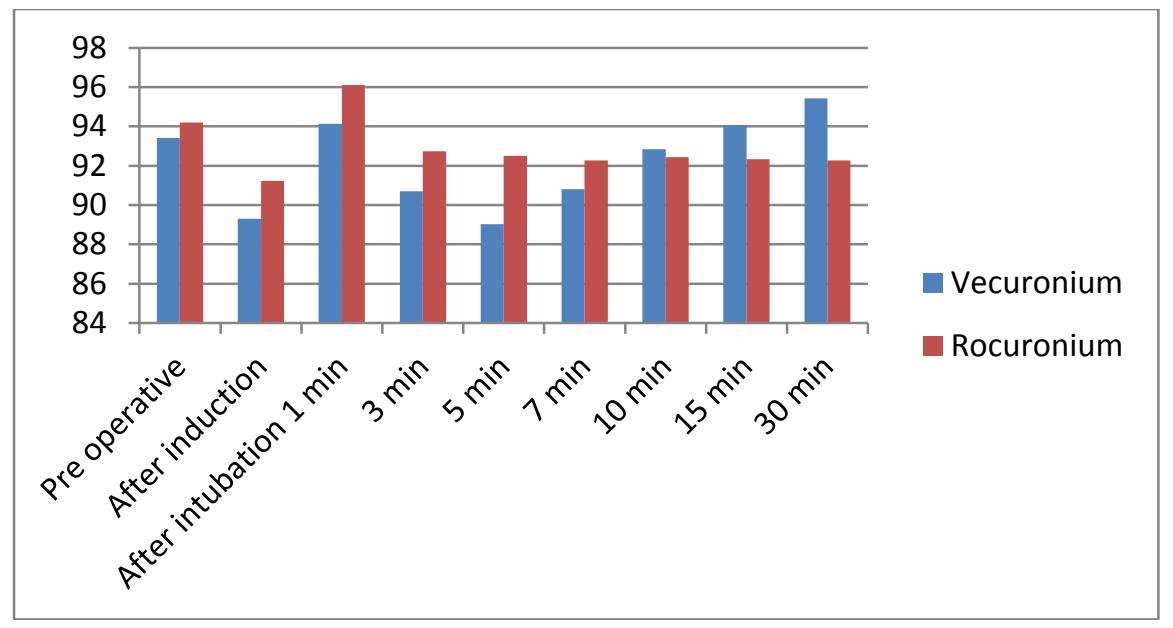

III. Discussion:

Vecuronium has maintained excellent cardiovascular stability for the dose used in present study. There was a decrease in heart rate following vecuronium administration in present study but the average maximum decrease was only of the order of five beats per minute, a decrease hardly of any clinical significance.

Rocuronium is three to six times less potent than vecuronium as a neuromuscular blocker but is slightly more potent in blocking the responses to either vagal or preganglionic sympathetic stimulation. Therefore the margin between the neuromuscular blocking effect and the unwanted vagal blocking action is less than that of vecuronium. Bradycardia and hypotension caused by many of the commonly used anaesthetic techniques may make drugs with mild vagal blocking effect more acceptable than drugs with complete lack of cardiovascular effects. In this respect rocuronium with mild vagolytic effect would have an advantage over vecuronium. 
Rocuronium has the advantage of rapid onset and intermediate duration of action. The reason for this rapid onset of neuromuscular block has been suggested to be the low potency of rocuronium, entailing the presence of more relaxant molecules in the blood stream which results in a large concentration gradient towards the biophase 22 . The rate of onset of neuromuscular blocking action is affected by anaesthetic technique: if relaxant is given immediately after the induction agent, then the onset time is few seconds longer than when steady-state anaesthesia has already been achieved with a volatile agent. The maximal average increase in heart rate is far smaller and clinically acceptable.

In describing the characteristics of an ideal neuromuscular blocking agent Savarese and Kitz in 1973', pointed out the importance of a fast onset of action, a short duration, cardiovascular stability, lack of accumulation and easy reversibility. Other desirable features of the ideal muscle relaxant are the absence of histamine liberation, no significant drug interactions, no increased effect on intraocular or intra-cranial pressures and the absence of metabolites with and significant pharmacological effect.

Cardiovascular effects of muscle relaxant may be produce by muscarinic receptor block, ganglion block, increased noradrenaline release and blockade of its uptake, or histamine liberation. Neuromuscular blocking agents vary widely with regard to their cardiovascular effects. Among the established agents, tubocurarine, gallamine and pancuronium exert significant cardiovascular effects; astracurium and mivacurium produce minor changes in cardiovascular variables while vecuronium and rocuronium are associated with a high degree of cardiostability.

\section{Heart Rate}

In the present study in the group I insignificant fall in heart rate was observed following induction. The value was 83.4 as compared to the basal value of 84.2 beats $/ \mathrm{min}$. After one minute of endotracheal intubation the heart rate increased. The rise in heart rate after intubation was not significant statistically. The heart rate gradually decreased after 5 and 10 minute of intubation and came towards basal value and then further decreased reaching below the basal heart rate after 30 minutes $(76.6$ beats $/ \mathrm{min}$.), which was statistically significant $(\mathrm{p}<0.05)$ as compared with basal heart rate as shown in table VI. Owing to the rapid clearance of vecuronium from plasma, any peripheral effects on the cardiovascular system would be evident within 10 minute of its administration.

In the group II after rocuronium administration heart rate increased to 85.3 beats $/ \mathrm{min}$. from the basal value of 83.83 beats/min (statistically insignificant). After one minute of intubation heart rate increased to 91 beats/min but was insignificant statistically.

In this comparative study of rocuronium and vecuronium in equipotent doses the administration of rocuronium was associated with a small increase in heart rate of 7\% and a slight decrease of the arterial blood pressure of 5\% (not statistically). The cardiovascular profile of the three increasing intubating doses was similar and none of the three doses had any adverse effect on the cardiovascular function of any of the patients.

Surprisingly Booth and colleagues ${ }^{23}$ found an increase of greater than $30 \%$ in heart rate with a dose of 0.6 $\mathrm{mg} / \mathrm{kg}$ of rocuronium.

\section{Mean arterial pressure}

In the present study in the group I after administration of vecuronium a fall in mean arterial pressure was seen from basal value of 93.4 to $89.3 \mathrm{mmHg}$ which was insignificant statistically. Morris et al $(\mathbf{1 9 8 3})^{16}$ andRoervik et al (1988) ${ }^{17}$ showed that vecuronium has a large margin of safety between the neuromuscular and vagal blocking effects and shows cardiovascular stability even when used in higher doses.

In the group II an insignificant fall in mean arterial pressure from basal value of 94.2 to 91.23 after rocuronium and thiopentone administration was seen. 1 minute after intubation arterial pressure increased to $94.3 \mathrm{mmHg}$. The changes in mean arterial pressure were statistically insignificant $(p>0.05)$.

Histamine liberation can be a significant factor in the haemodynamic effects of neuromuscular blocking drugs. This may be direct effect or caused by interaction with an enzyme such as the complement cascade. Moss et al (1983) ${ }^{\mathbf{1 0}}$ demonstrated that there is a good correlation between plasma histamine levels of about $10-20 \mathrm{ng} / \mathrm{ml}$ causing hypotension and bronchospasm and plasma histamine concentrations greater than $100 \mathrm{ng} / \mathrm{ml}$ leading to possible irrecoverable collapse. This confirmation with the haemodynamic stability observed in cats by Cason et al (1990) ${ }^{\mathbf{2 1}}$.

Similar to the present study Robertson et al (1994) ${ }^{30}$ found $10-15 \%$ increase in the mean arterial pressure after administration of $0.9 \mathrm{mg} / \mathrm{kg}$ of rocuronium, whereas, McCoy et al (1994) ${ }^{27}$ found no significant change in mean arterial pressure following rocuronium. Pancuronium was associated with a significant increase in mean arterial pressure, end-diastolic areas and heart rate, none of which were seen after rocuronium at either dose level. Maddineni et al (1994) ${ }^{29}$ found no significant changes in mean arterial pressure while using 0.6 $\mathrm{mg} / \mathrm{kg}$ or $0.9 \mathrm{mg} / \mathrm{kg}$ of rocuronium under either balanced or volatile anaesthesia. 
With this study it was found that our results in respect to heart rate and mean arterial pressure were consistent with the finding of McCoy et al (1993) ${ }^{27}$, Morris et al $(\mathbf{1 9 8 3})^{16}$ andMaddineni et al $(\mathbf{1 9 9 4})^{29}$. In our study rocuronium was found to be more stable haemodynamically than vecuronium.

\section{Intubating conditions}

We have found that rocuronium provides clinically acceptable intubating conditions much earlier than vecuronium. Previous studies have shown that the onset of action at the laryngeal abductor muscles is markedly shorter for rocuronium than for vecuronium. The reason for this rapid onset of neuromuscular block has been suggested to be low potency of rocuronium, entailing the presence of more relaxant molecules in the blood stream which results in a large concentration gradient towards the biophase at pre and post synaptic receptor sites at neuromuscular junction. Another possible explanation is that plasma protein binding of rocuronium is less than vecuronium. Bartowsky et al (1993) ${ }^{\mathbf{2 5}}$ also showed that onset time for rocuronium was significantly faster than vecuronium. In the present study, time to maximum block (T1) for vecuronium was 150.7 second and for rocuronium was 99.97 seconds which was highly significant for rocuronium as shown in table III. The intubation score for vecuronium and rocuronium were 8.87 and 8.93 respectively (As shown in table IV) and in about $90 \%$ of patients in both the groups, the intubating conditions were graded as adequate.

Previous research studies have shown that, compared with suxamethonium $1 \mathrm{mg} / \mathrm{kg}$, rocuronium 1.2 $\mathrm{mg} / \mathrm{kg}$ produced similar intubating conditions and similar mean times to complete intubation. Intubation. However, such an intubating dose of rocuronium is associated with a longer time to maximal depression of T1 and longer clinical duration of action than suxamethonium. Recently it was found that rocuronium in dose of 3 or 4 times $\mathrm{ED}_{95}(0.9 \mathrm{mg} / \mathrm{kg}-1.2 \mathrm{mg} / \mathrm{kg})$ significantly shortened the onset time to a value same as that for suxamethonium $1 \mathrm{mg} / \mathrm{kg}$ (Magorian T, Flannery KB, Miller RD) ${ }^{26}$.

\section{Result}

Haemodynamic stability is an integral and essential goal of any anaesthetic management plan in patients undergoing surgical procedures. It would therefore be reasonable to avoid any agents, including muscle relaxants, which give rise to stimulation of cardiovascular system and thus increase myocardial oxygen demand. The present study showed that both vecuronium and rocuronium were associated with clinically unimportant haemodynamic changes, although the changes in some variable were occasionally statistically significant.

To conclude rocuronium, in clinical doses, is associated with good haemodynamic stability \& intubating conditions as compared to vecuronium in ASA grades I or II patients undergoing elective general surgical procedures.

\section{References}

[1]. Aparna Shukla, K. P. Dubey, M. S. N. Sharma, Indian J. Anaesth. 2004 476; 48 (6): 476-479.

[2]. Misra, Agarwal, Pandey, Gupta Indian J. Anaesth. 2005; 49 (6): 469 - 473.

[3]. Fuchs-Buder T, Tassonyi E. Intubating conditions and time course of rocuronium-induced neuromuscular block in children. Br $\mathrm{J}$ Anaesth. 1996; 77: 335-338.

[4]. Tolmie JD, Joyce TH, Mitchell GD. Succinylcholine danger in the burned patient. Anaesthesiology.1967;28:167-70.

[5]. Griffith KE, Joshi GP, Whitman PF, Garg SA. Priming with rocuronium accelerates the onset of neuromuscular blockade. J ClinAnaesth. 1997; 9:204-207.

[6]. Heier T, Caldwell JE. Rapid tracheal intubation with large dose rocuronium: A probability-based approach. AnaesthAnalg. 2000; 90:175-179.

[7]. Wierda JM KH et al. Pharmacokinetics and pharmacokinetic/ dynamic relationship of rocuronium bromide in humans. Eur $\mathbf{J}$ Anaesth 1994; 11: 66-74.

[8]. Hunter JM. Rocuronium - The newest aminosteriod neuromuscular blocking drug. Br J Anaesth 1996; 76 : 481 -483.

[9]. Savarese JJ. Kitz RJ: Does clinical anesthesia need new neuromuscular blocking agents? Anesthesiology 1975;42 (3): 236-239.

[10]. Moss J, Rosowin CE: Histamine release by narcotics and muscle relaxants in humans. Anesthesiology 1983; 59(4): 330-339.

[11]. Crul and Booij : First clinical experience with vecuronium (ORG NC-45). Br J Anaesth. 1980; 495

[12]. Krieg N, Mazur F, Booji H.D.,Crul J.F.: Intubating condition and reversibility of a new non depolarizing muscle relaxant ORG NC45. Acta-Anaesth.1980; Scandi-24: 423.

[13]. Harrison P.,Fildmann S.A.: Intubation condition with ORG NC-45 Anaesthesiology. 1981;Sep;36(9):874-7

[14]. Fahey R, Morris B., Miller D.R., Sohn J.Y.: Clinical pharmacology of ORG NC-45. Anaesthesiology, 1981; 55:6.

[15]. Mirakhur RK, Ferres CJ, Clarke RSJ Bali I, Dundee Jw: Clinical evaluation of ORG NC-45. Br J Anaesth. 1983; 55:119-124.

[16]. Morris R.B., Cahalan M.K., Miller R.D., Wilkinson P.L., QuashaA.l., Robinson S.L.: The cardiovascular effects of vecuronium (ORG NC-450) an d pancuronium in patients undergoing coronary artery bypass grafting. Anesthesiology 1983; 58:438-440.

[17]. Roevik K, Husby P. Gramstad L.,Vamnes J.S., Bitsch-Larsen L., Koller M.E.: Comparison of large dose of vecuronium with pancuronium for prolonged neuromuscular blockade. Br J Anaesth. 1988; 61: 180-185.

[18]. Ginsberg B, Glass PS, Quilt T, ShafronD,Osset KD : Onset and duration of neuromuscular blockade following high dose vecuronium administration. Anaesthesiology 1989; 71:201-5.

[19]. Muir AW, Houston J, Green KL, Marshall RJ, Bowman WC, Marshall IG: Effects of a new neuromuscular blocking agent (Org 9426) in anaesthetized cats and pigs and in isolated nerve muscle preparations. Br J Anaesth 1989; 63: 400-410.

[20]. Wierda JMKH, De Wit APM, K, Agoston S: Clinical observations on the neuromuscular blocking action of ORG 9426, a new steroidal non-depolarizing agent Br J Anaesth. 1990; 64:521-523. 
[21]. Cason B, Baker D.G., Hickey R.F., Miller R.D., Agoston S: Cardiovascular and neuromuscular effects of three steroidal neuromuscular blocking drugs in dogs (Org 9619, Org 9426, Org 9991). Anesthesia Analgesia. 1990; 70:382-388.

[22]. Wiedra JM, Schuringa M, Van den Broekl: Cardiovascular effects of an intubating dose of rocuronium $0.6 \mathrm{mg} / \mathrm{kg}$ in anaesthetized patients, paralysed with vecuronium. British Journal of anaesthesia; 1991; 78(5):586-7.

[23]. Booth MG, Marsh B, Bryden FMMM. Robertson EN, Baird WLM: A comparison of pharmacodynamics of vecuronium and rocuronium during halothane anaesthesia. Anaesthesia 1992; 47:832-834.

[24]. Cooper RA, Mirakhur RK, Maddineni VR: Neuromuscular effects of rocuronium bromide (Org 9426) during fentanyl and halothane anaesthesia. Anaesthesia 1993; 48:103-105.

[25]. Bartkowski RR, Witkowski TA, Azad S, Lessin J, Marr A. Rocuronium onset of action: a comparison with atracurium and vecuronium. AnesthAnalg. 1993; 77(3):574-8.

[26]. Magorian T., Flannery K.B., Miller R.D.: Comparison of rocuronium, succinclcholine, and vecuronium for rapid sequence induction of anaesthesia in adults. Anaesthesiology. 1993; 78(5): 913.

[27]. McCoy EP, Maddineni VR, Elliot P, Mirakhur RK, Carson IW, Cooper RA: Haemodynamic effects of rocuronium during fentanyl anaesthesia: comparison with vecuronium. Canadian journal of Anaesthesia 1993; 40:703-8.

[28]. Appadu B.L., Lambert D.G. : Studies on the interaction of steroidal neuromuscular blocking drugs with cardiac muscarinic receptors Br-J-Anaesth. 1994; 72(1): 86.

[29]. Maddineni VR, McCoy EP, Mirakur RK, McBride RJ.Onset, duration of action and haemodynamic effects of rocuronium bromide under balanced and volatile anesthesia. ActaAnaesthesiol Belg. 1994; 45(2):41-7.

[30]. Robertson EN, Hull JM, Verbeek AM, Booij LHDJ: A comparison of rocuronium and vecuronium : the pharmacodynamic, cardiovascular and intra-ocular effects. Eur J Anaesth. 1994; 11 (9): 116-121. 